\section{What is the scientific name of jack pine?}

Dear Sir:

In the February issue of

The Forestry Chronicle the scientific name of jack pine has been changed

from Pinus banksiana Lamb. to Pinus divaricata (Ait.) Dumont.

(Hardiness of jack pine hybrids and provenances in the boreal forest by C.W Yeatman and

M. J. Holst and A close up of the stomatal regions of white spruce and jack pine by $A$. Lehela,

R. J. Day and Z. Koran).

Could someone explain the reasons for the change since I have missed any previous mention and discussion of a proposed change. I have always considered the scientific name of a species to be the proper name, one which

facilitated communication by reducing confusion to a minimum. Is this change really necessary?

Fred C. Robinson, R.P.F. Willowdale, Ont.

Yes, Mr. Robinson, you are entitled to an explanation. The reason for the change was summarized succinctly by George W. Argus of the Canadian Forestry Service in the Canadian Journal of Botany, Volume 39, pages 573-576. In that article he wrote: "When the scientific name of a common and economically important tree species such as jack pine is changed, foresters and botanists alike may well expect a detailed explanation of the reasons for the change." Argus was not satisfied with the explanation he had read so delved into the matter himself. Pinus divaricata (Ait.) Dumont, he concluded, has priority of P. banksiana Lamb. as the correct name for jack pine.

The matter appeared settled to some people. However, the detectives are still at work and his conclusions may be wrong. Here is a condensation of the article by Argus.

The epithet divaricata was first used in 1789 by Aiton in Hortus Kewensis for a variety of the European Scots pine, Pinus sylvestris $L$. The material on which the original diagnosis was based was cultivated in the Royal Botanic Garden at Kew and originated in the "Hudson's Bay" region. The diagnosis of var. divaricata ("foliis divaricatis obliquis") refers to the characteristically spreading leaves of jack pine. Although this diagnosis is brief it describes features that, in the opinion of Aiton, distinguish this taxon from all others and under the International Code of Botanical Nomenclature, Art. 32, such a diagnosis is adequate to constitute valid publication. The name Pinus sylvestris var. divaricata is legitimate in accordance with the International Code and it would be the correct name if a taxonomist wished to treat jack pine as a variety of Scots pine.

In 1802, the French agronomist, Dumont de Courset changed the epithet divaricata from varietal to specific rank in his Le Botaniste Cultivateur. In making the change Dumont referred to the original diagnosis by use of the abbreviation "H. K.," which refers to Aiton's then well-known Hortus Kewensis. This reference to the original description is adequate to conform to the International Code.

The name Pinus divaricata is legitimate and the correct name for jack pine when that taxon is treated taxonomically as a distinct species.

In 1803, A. B. Lambert wrote A Description of the Genus Pinus in which the species Pinus banksiana was described and beautifully illustrated by a color plate. Lambert included a description, "P. foliis geminus divaricatis obliquis, strobulis recurvis tortis, antherarum crista dilatata," and cited "P. sylvestris divaricata $\delta$ Ait. Kew. v. 3. 366" as a synonym.

This name was validly published in accordance with the International Code; but it is a name to be rejected because it is antedated by Dumont's combination published in 1802

\section{Use of the name}

The name Pinus divaricata appears to have eluded North Ameriican taxonomists for a long time. The earliest use of this name is apparently in 1897 by C. S. Sargent in Silva of North America, 95 years after its original publication. However, Aiton's use of divaricata as a variety of $\mathbf{P}$. sylvestris was well known and the variety was frequently cited as a syno- nym of Pinus banksiana.

Before Sargent used P. divaricata, G. B. Sudworth, dendrologist with the U.S. Forest Service, wished to raise Aiton's var. divaricata to species rank apparently following a strict interpretation of priority, in which the earliest epithet in any rank whatsoever had priority as the correct name for a taxon. In 1893, Sudworth discussed the problem of the correct name for jack pine and concluded that, "The name for this pine should then be Pinus divaricata (Aiton) $=\mathbf{P}$. sylvestris divaricata (Aiton 1789) = Pinus banksiana Lambert (1903)." Before he could use his new combination he found that Gordon 1858 had cited "P. divaricata Hort." as a synonym of P. banksiana and, considering that this represented an earlier publication of divaricata at the species level, used Gordon's name in his Nomenclature of the Arborescent Flora of the United States (1897).

In 1897, Sargent found that Dumont had published the name $\mathbf{P}$. divaricata in 1802 and Sargent used that name in his Silva of North America. Following Sargent, Sudworth used Dumont's name in his 1898 Check List of the Forest Trees of the United States and in 1905 Sargent again used that name in his Manual of the Trees of North America (1st ed.). With the use of $\mathbf{P}$. divaricata Dumont in these three wellknown and authoritative works one would expect that Dumont's name would have been firmly entrenched in the forestry and taxonomic literature, but this was not so. For just as rapidly as this name appeared in use at the end of the 19th century it disappeared from use, except in synonymy, in the first 2 decades of the 20th century.

\section{Rejection of the name}

In 1907 Sargent proposed name changes in North American trees, including P. divaricata to P. banksiana, supposedly in accordance with the Vienna Code of botanical nomenclature, which was then accepted by many North American taxonomists who had formerly adhered to the American Code or to one of the various interpretations of the general "American Code". Sargent does 
not say why he rejected $\mathbf{P}$. divaricata, but it can be assumed that it was due to a misunderstanding of the then newly accepted International Code of Botanical Nomenclature. Subsequently Sargent used the name $\mathbf{P}$. banksiana in the Manual of the Trees of North America, ed. 2 (1922) and his decision received the support of Sudworth in 1927.

In 1908 Graebner maintained that the description of var. divaricata was inadequate to ascertain the identity of the taxon and must be rejected as not in accordance with the Vienna Code. Suringar reviewed Graebner's argument in 1927 and agreed that if a taxonomist is of the opinion that the description of var. divaricata is inadequate then that name should be rejected. Recently, E. L. Little, Jr. in 1953 followed the same argument and included $\mathbf{P}$. divaricata as a synonym of $\mathbf{P}$. banksiana.

Aiton's original description of var. divaricata was very brief; however, it has not led to any confusion about the identity of the taxon. If certain of the characteristics of $\mathbf{P}$. sylvestris (of which the variety was a part) are considered, namely, its two, stiff leaves sheathed at the base, along with the geographical origin of the original material, the identity of the variety is unequivocal. The only other pine in the Hudson Bay region having two leaves in a bundle is $\mathbf{P}$. resinosa Mill., the red pine, which
Aiton knew and clearly described in Hortus Kewensis. Furthermore, in Lambert's original description of $\mathbf{P}$. banksiana he cited $\mathbf{P}$. sylvestris var. divaricata as a synonym showing that even he was in doubt about the identity of divaricata. This view has been held by many botanists who cite the variety as a synonym of $\mathbf{P}$. banksiana whether or not they are aware of Dumont's transfer.

A second argument, that Dumont's name was not published until 1811 in the second edition of Le Botaniste Cultivateur (Vol. 6, p. 457) and is therefore a later name than Lambert's P. banksiana published in 1803, has been used. An examination of the first edition of Dumont's publication refutes this argument.

A review of the evidence shows that the names Pinus sylvestris L. var. divaricata Aiton and P. divaricata (Aiton) Dumont are validly published and legitimate names. If the jack pine is considered, taxonomically, to be a distinct species then, according to the rules of priority, International Code, Art. 11, P. divaricata is the correct name and the later name $\mathbf{P}$. banksiana Lamb. must be treated as its synonym. Without question this is the correct nomenclatural decision.

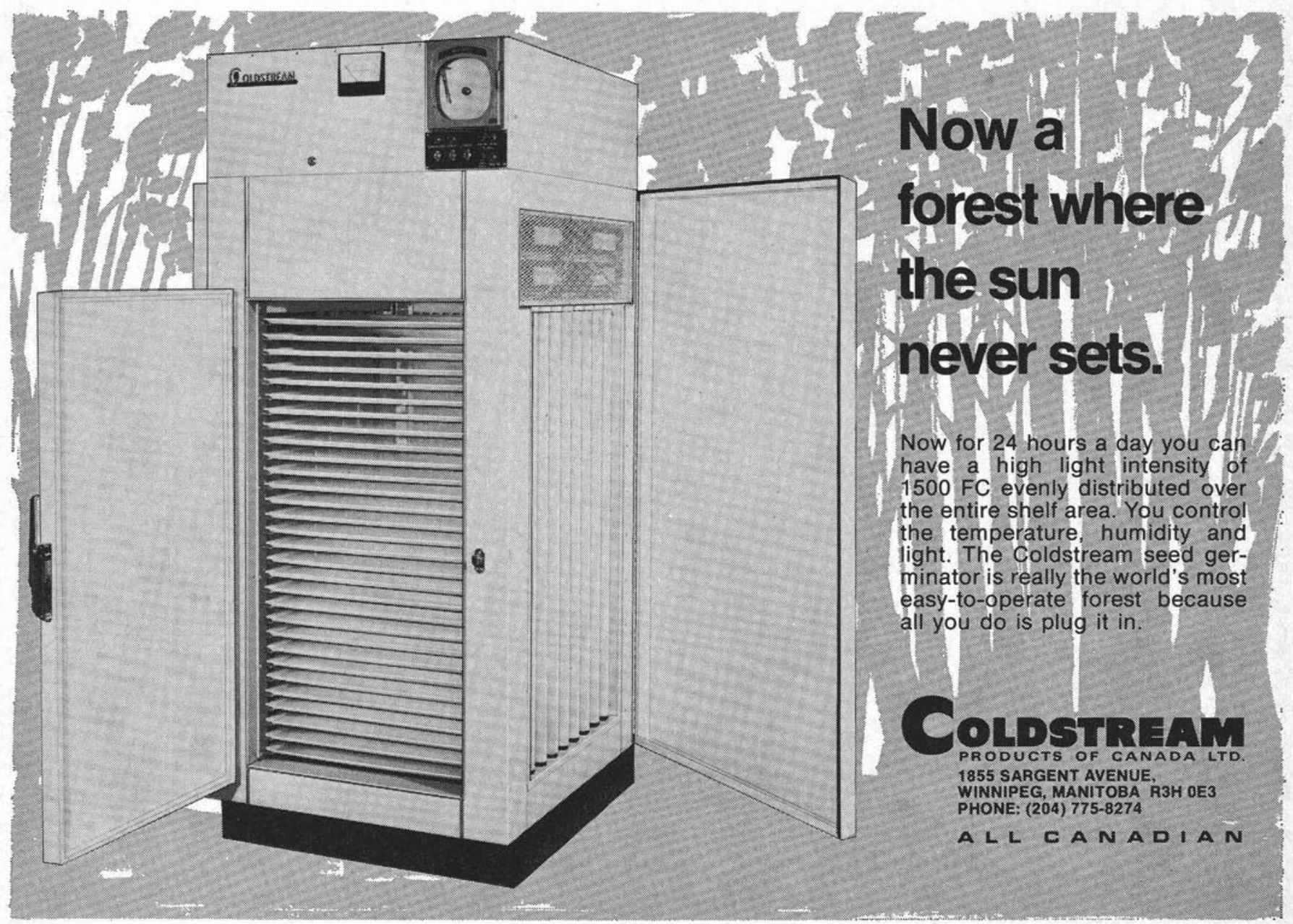

